Revista Eletrônica do Mestrado em Educação Ambiental

Programa de Pós-Graduação em Educação Ambiental

\title{
O mundo das plantas Kariri-xocó: criações poéticas e fotográficas com o grupo
}

\section{Sabuká}

\author{
Alik Wunder ${ }^{1}$ \\ Universidade Estadual de Campinas \\ ORCID http://orcid.org/0000-0003-2336-7000
}

\begin{abstract}
Resumo: Este trabalho traz criações fotográficas e narrativas orais na forma de um ensaio poético e visual, realizado com o grupo indígena Sabuká Kariri-Xocó. Partimos de uma perspectiva de pesquisa acadêmica na qual a experimentação do pensamento dá-se no movimento inventivo com as imagens e com as palavras. Desejamos manter aberta uma zona de vizinhança, na qual o pensamento acadêmico é atravessado por outros modos de expressão e percepção do mundo. $\mathrm{O}$ trabalho é resultado de um projeto de intercâmbio realizado há 8 anos na Universidade Estadual de Campinas com a aldeia Kariri-Xocó de Porto Real do Colégio, situada no estado de Alagoas (Brasil). Os Kariri-Xocó abrem-nos aos devires indígenas pelos seus cantos, suas imagens, suas narrativas, seus sonhos e relações com o universo vegetal, abrem espaços/tempos de partilhas sobre seus modos de existir e resistir.
\end{abstract}

Palavras-chaves: imagem; povos indígenas; criação

\section{El mundo de las plantas Kariri-xocó: creaciones poéticas y fotográficas con el}

\section{grupo Sabuká}

Resumen: Este trabajo trae creaciones fotográficas y narraciones orales en forma de ensayo poético y visual, realizado con el grupo indígena Sabuká Kariri-Xocó. Partimos de una perspectiva de investigación académica en la que la experimentación del pensamiento tiene lugar en el movimiento inventivo con imágenes y palavras. Queremos mantener abierta esta área del vecindario, en la cual el pensamiento académico se cruza con otros modos de expresión y percepción del mundo. El trabajo es el resultado de un proyecto de intercambio llevado a cabo hace 8 años en la Universidad Estatal de Campinas con el pueblo Kariri-Xocó de Porto Real do Colégio, ubicado en el estado de Alagoas (Brasil). Los Kariri-Xocó los abren a los devenires indígenas através de sus canciones, sus imágenes, sus narrativas, sus sueños y relaciones con el

\footnotetext{
${ }^{1}$ Bióloga, mestre, doutora e pós-doutora em Educação, docente e pesquisadora da Faculdade de Educação da Universidade Estadual de Campinas (SP, Brasil). e-mail: alik.wunder@gmail.com
}

Rev. Eletrônica Mestr. Educ. Ambient. Rio Grande, Dossiê temático "Imagens: resistências e criações cotidianas", p. 28-42, jun. 2020. E-ISSN 1517-1256 
universo vegetal, abren espacios / momentos de intercambio sobre sus formas de existir y resistir.

Palabras llave: imagen; pueblos indígenas; creación

\title{
The world of Kariri-xocó plants: poetic and photographic creations with Sabuká group
}

\begin{abstract}
This work brings photographic creations and oral narratives in the form of a poetic and visual essay, carried out with the indigenous group Sabuká Kariri-Xocó. We start from an academic research perspective in which the experimentation of thought takes place in the inventive movement with images and words. We want to keep this neighborhood area open, in which academic thought is crossed by other modes of expression and perception of the world. The work is the result of an exchange project carried out 8 years ago at the State University of Campinas with the Kariri-Xocó of Porto Real do Colégio, located in the state of Alagoas (Brazil). The Kariri-Xocó open their indigenous universe through their songs, their images, their narratives, their dreams and relationships with the plant universe, they open spaces / times of sharing about their ways of existing and resisting.
\end{abstract}

Keywords: image; indigenous people; creation

\section{Introdução}

Os povos indígenas oferecem-nos outras imagens, outras visualidades, mundos outros. Desde 2013, o grupo Sabuká Kariri-Xocó realiza na cidade de Campinas-SP, encontros em escolas e universidade sobre seus modos de vida, cosmovisões, conhecimentos e celebrações com cantos e danças intituladas Torés. Desde a primeira vez que recebemos os Sabuká em Campinas, criamos uma rede de apoio ao grupo, formada por professores/as, estudantes e artistas para acolhê-los por alguns dias na cidade. A rede organiza os encontros e possibilita diversos intercâmbios com crianças, jovens, educadores/as, artistas, ativistas, pesquisadores/as... Como parte dos movimentos da rede de apoio, desenvolvemos na Universidade Estadual de Campinas um intercâmbio com a aldeia Kariri-Xocó de Porto Real do Colégio, situada no estado de Alagoas (Brasil). Os Kariri-Xocó abrem-nos aos devires indígenas pelos seus cantos, suas imagens, suas narrativas, seus sonhos e relações com o universo vegetal, abrem espaços/tempos de partilhas sobre seus modos de existir e resistir.

A entrada na visualidade e no "mundo das plantas" Kariri-Xocó se fez especialmente em encontros de criação conjunta de imagens fotográficas entre nosso grupo de pesquisa e criação, o Coletivo Fabulografias e os indígenas, em encontros que chamamos de ateliês experimentais. Abrimos, nestes anos, espaços/tempos de encontros coletivos de criação, de contação de histórias, partilhas e pesquisa que se fazem entre as formas de ver e criar imagens dos Kariri-Xocó e nossos modos de ver e criar imagens. Rev. Eletrônica Mestr. Educ. Ambient. Rio Grande, Dossiê temático "Imagens: resistências e criações cotidianas", p. 28-42, jun. 2020. E-ISSN 1517-1256 
Este trabalho traz criações visuais e narrativas orais na forma de um ensaio poético e visual. Partimos de uma perspectiva de pesquisa acadêmica na qual a experimentação do pensamento dá-se no movimento inventivo com as imagens e com as palavras, de modo que as fronteiras entre pesquisa, literatura e artes visuais sejam borradas. Desejase manter aberta esta zona de vizinhança, na qual o pensamento acadêmico é atravessado por outros modos de expressão e percepção do mundo.

Oferecemos aos Kariri-Xocó nossas imagens, em geral fotografias e eles/elas nos ofereceram as suas histórias, suas pinturas corporais, suas artes materiais, suas imagens de sonhos, imagens de cantos... Por meio destes encontros, lentamente nos enredamos e criamos com seu universo imagético e cosmovisões. As imagens criadas nos ateliês experimentais são pensadas como travessias silenciosas, como possibilidade de coabitarmos mundos distintos no ato de criação conjunta. Imagens como superfícies de encontros, como entre mundos, uma dupla captura entre duas visualidades. Desejamos habitar e proliferar pensamentos desde esta zona de vizinhanças, que as experimentações imagéticas traçam. A imagem - fotografias desenhos, grafismos, traços, riscos - como uma contínua experimentação, como uma forma sempre inacabada de encontrar abrindo outras linhas visuais, outras percepções e outros pensamentos. Nestes primeiros encontros a força de seus corpos pintados, de suas danças e cantos, de suas artes materiais nos lançou a uma intensa criação fotográfica. Em 2015, no terceiro encontro anual, fizemos o convite a uma experiência fotográfica conjunta que se fez em dois movimentos: o primeiro foi a experiência de fotografar e o segundo de realizar intervenções - recortes, raspagens, desenhos - sobre um conjunto de fotografias que fizemos do grupo. Deste segundo movimento a visualidade dos grafismos deram contornos outros as superfícies fotográficas. As linhas de jenipapo - fruto que dá cor negra às pinturas corporais - transbordaram seus corpos e invadiram as fotografias. A visualidade Kariri-Xocó entrelaçou-se com as formas das fotografias criando uma superfície imagética híbrida. 


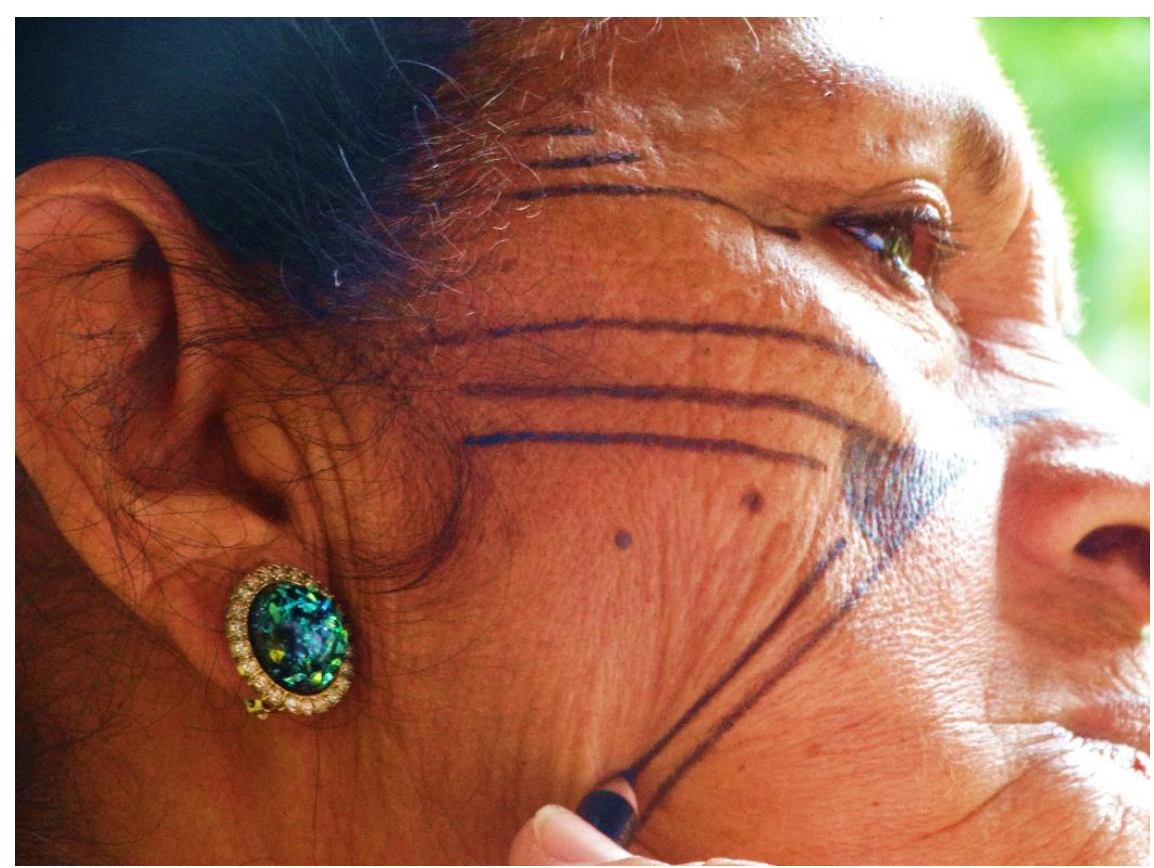

Imagem 1: foto de Alik Wunder - Dé Kariri-Xocó em ritual de pintura

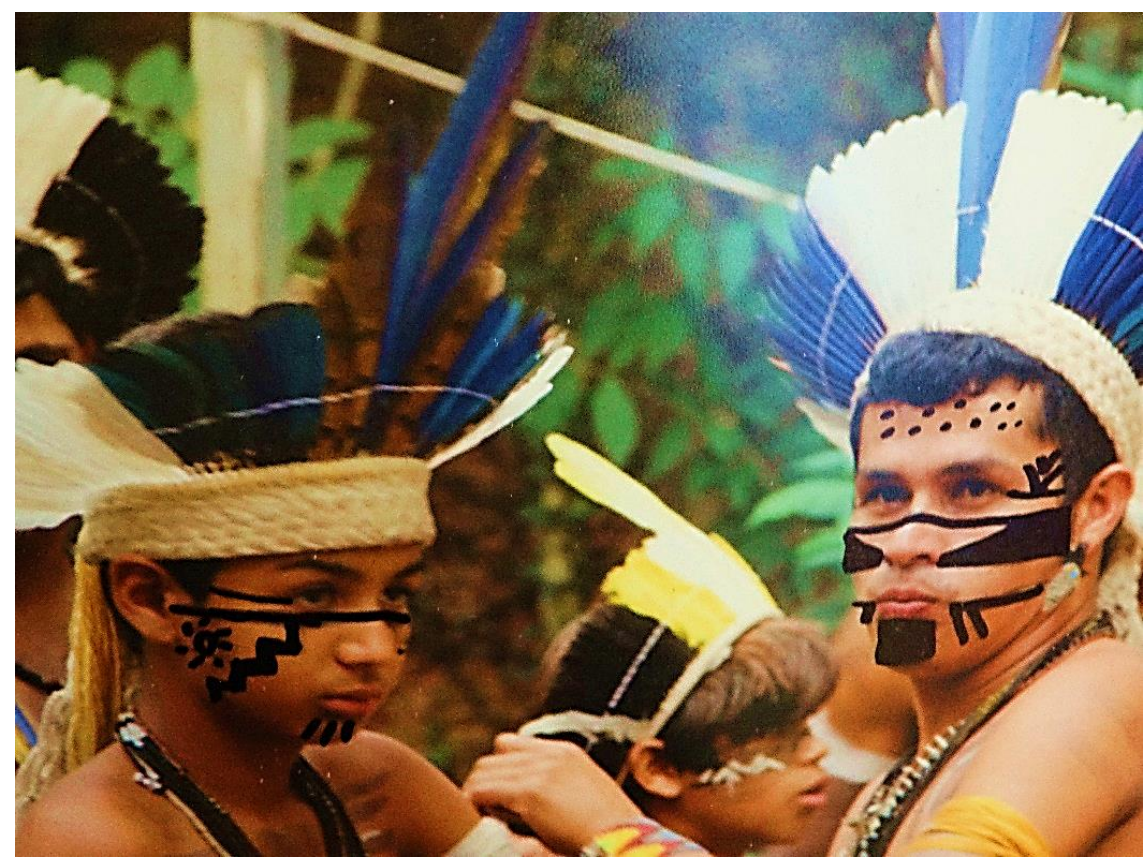

Imagem 2: foto de Marli Wunder - criação sobre foto Kauan Kariri-Xocó

Rev. Eletrônica Mestr. Educ. Ambient. Rio Grande, Dossiê temático "Imagens: resistências e criações cotidianas", p. 28-42, jun. 2020. E-ISSN 1517-1256 


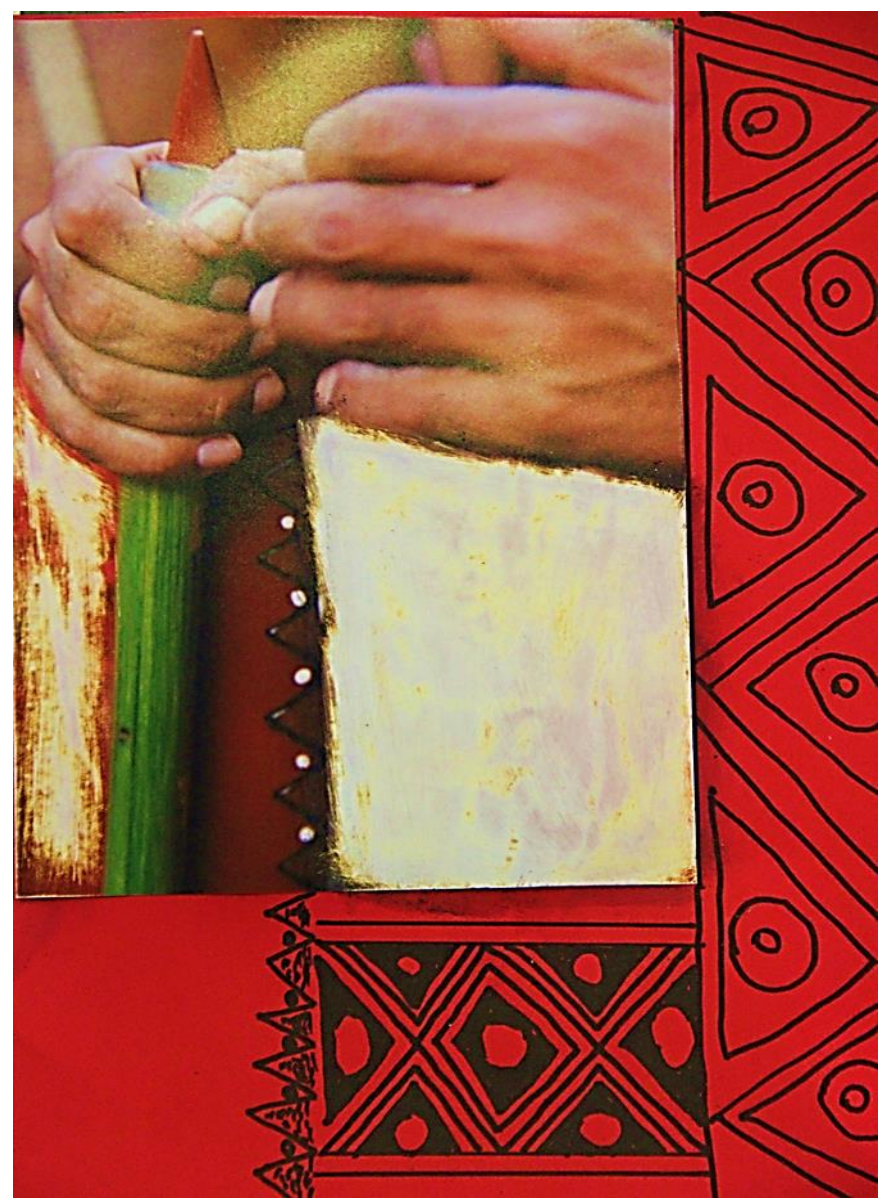

Imagem 3: foto de Marli Wunder - criação sobre imagem de Dirã Kariri-Xocó

Com a criação de novas imagem com técnica de raspagem das imagens com esponjas de aço, abriram-se luzes outras, criaram-se outras materialidades fotográficas, abriu-se espaço a imagens-sonhos e imagens-visagens. Pawanã Crodi, coordenador do grupo, após o encontro, olhando as criações deste primeiro ateliê disse-nos: "É a arte e a imaginação dando forma a nossa realidade”. Na abertura entre o visível fotografável e o campo invisível do sonho, as criações abriram no corpo-fotografia um espaço de encontro. Poderíamos pensar a imagem como um espaço ritual do encontro, como uma fronteira aberta? 


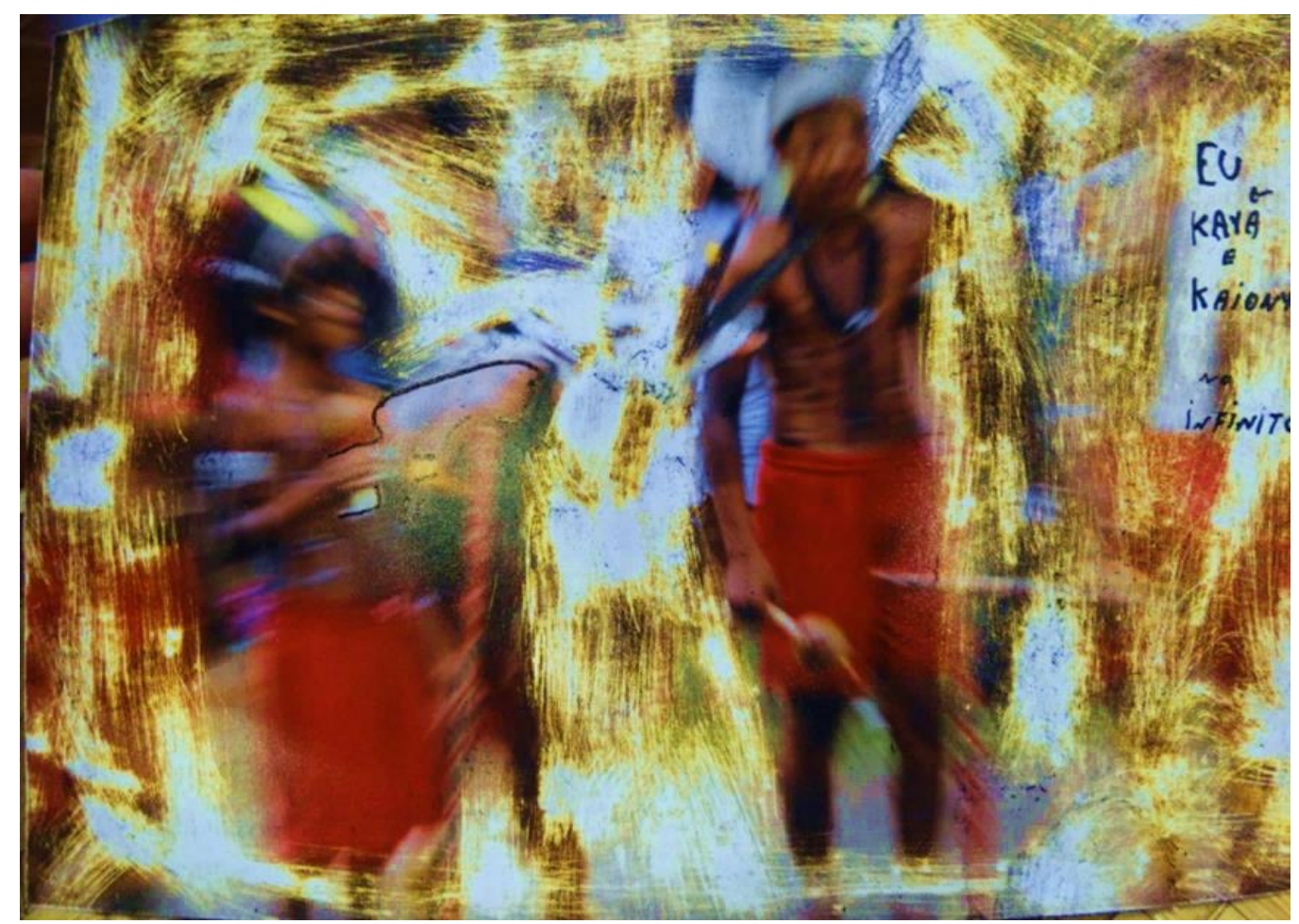

Imagem 4: Fotografia de Marli Wunder e criação sobre imagem de Pawanã Crodi Kariri-Xocó

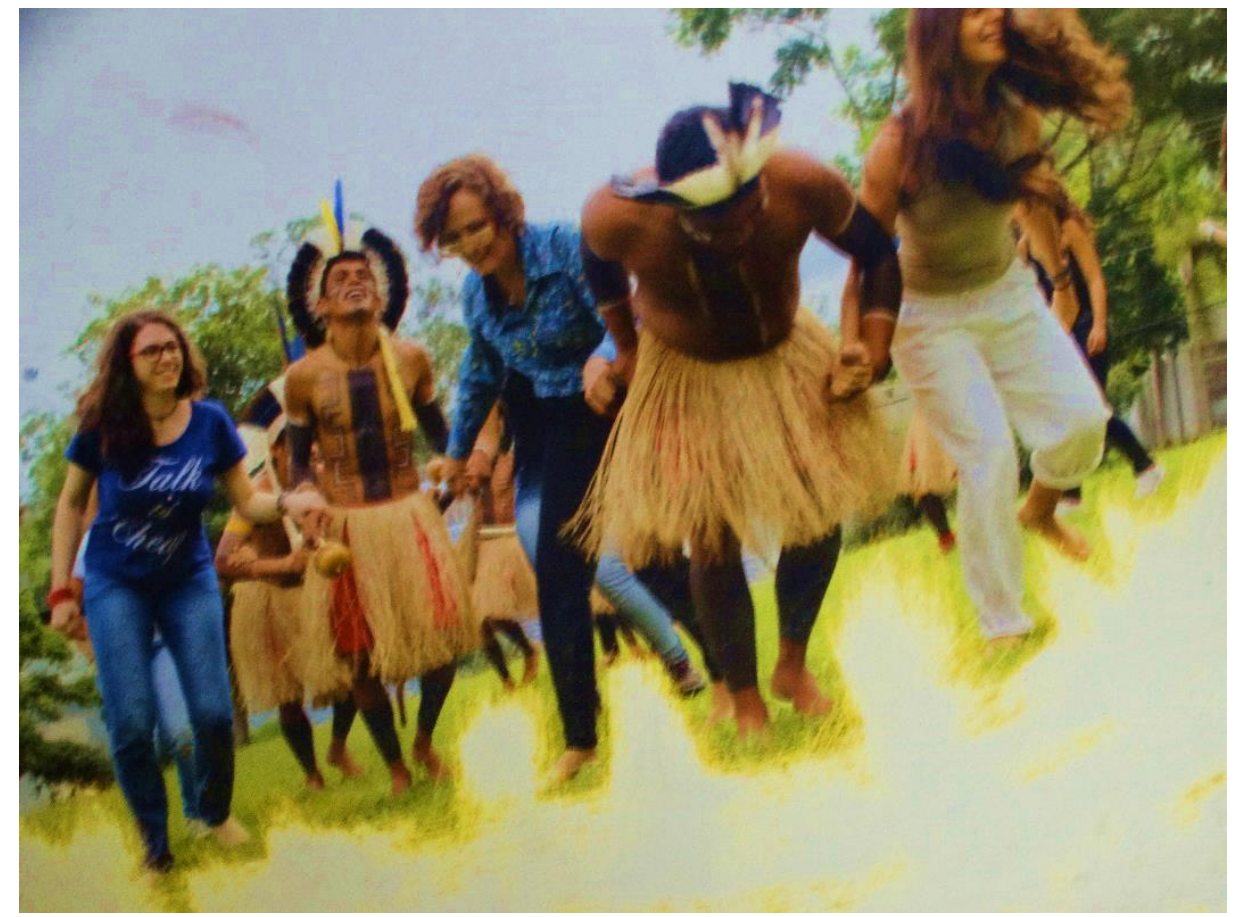

Imagem 5: Fotografia de Marli Wunder - criação sobre imahem Iaru Kariri-Xocó

Foi no primeiro movimento do ateliê de criação que o inesperado, o desdobramento mais radical da diferença, instaurou-se: na experiência de fotografar. Iniciamos com uma roda de conversa em que nós, pesquisadoras e fotógrafas, 
apresentamos nossos modos de criação com imagens. Falamos sobre os modos de compor luzes e sombras, cores, linhas e texturas a partir de uma pequena exposição. Fizemos convite para que também fotografassem e que, ao invés de colocarem atenção ao objeto/ser fotografados, se atentassem às luzes, sombras, cores e formas ... No entanto, o convite pareceu sem sentido e nenhum deles se movimentou para realizar fotografias. Estávamos em um grande jardim, repleto de frondosas árvores em uma casa de cultura, o Centro Cultural Casarão, local onde o grupo se hospeda na cidade. Percebendo que a experimentação fotográfica precisaria ganhar outro caminho, e já conhecendo as fortes relações dos Kariri-Xocó com o mundo vegetal, perguntei: "E se vocês fotografassem aquilo que as plantas vêm? E se nos mostrassem nas fotografias o mundo na perspectiva de visão das plantas?" Começaram a rir e seguiram para um exercício de fotografar não o jardim, mas com jardim.

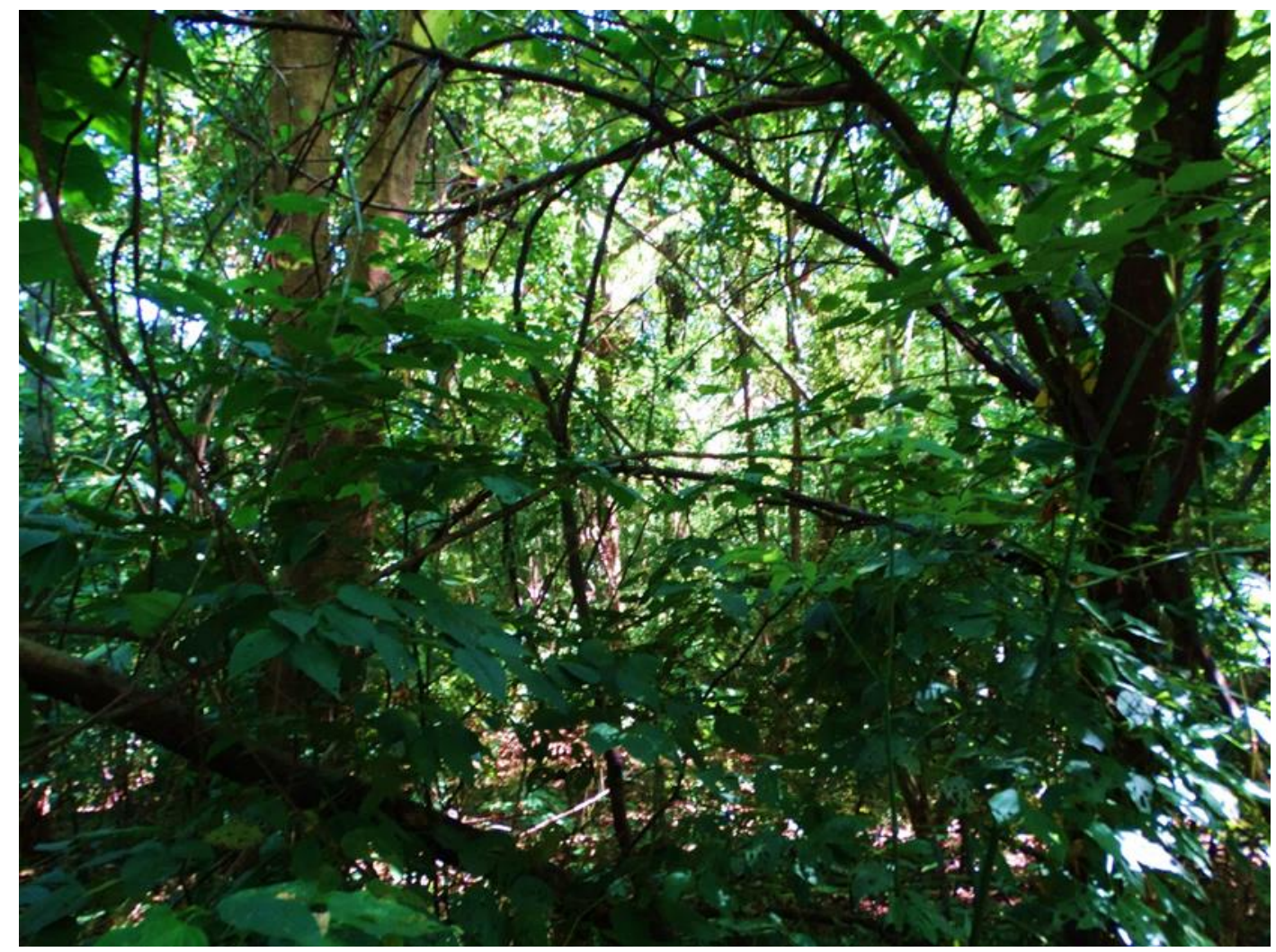

Imagem 6: foto de Kaony Kariri-Xocó 


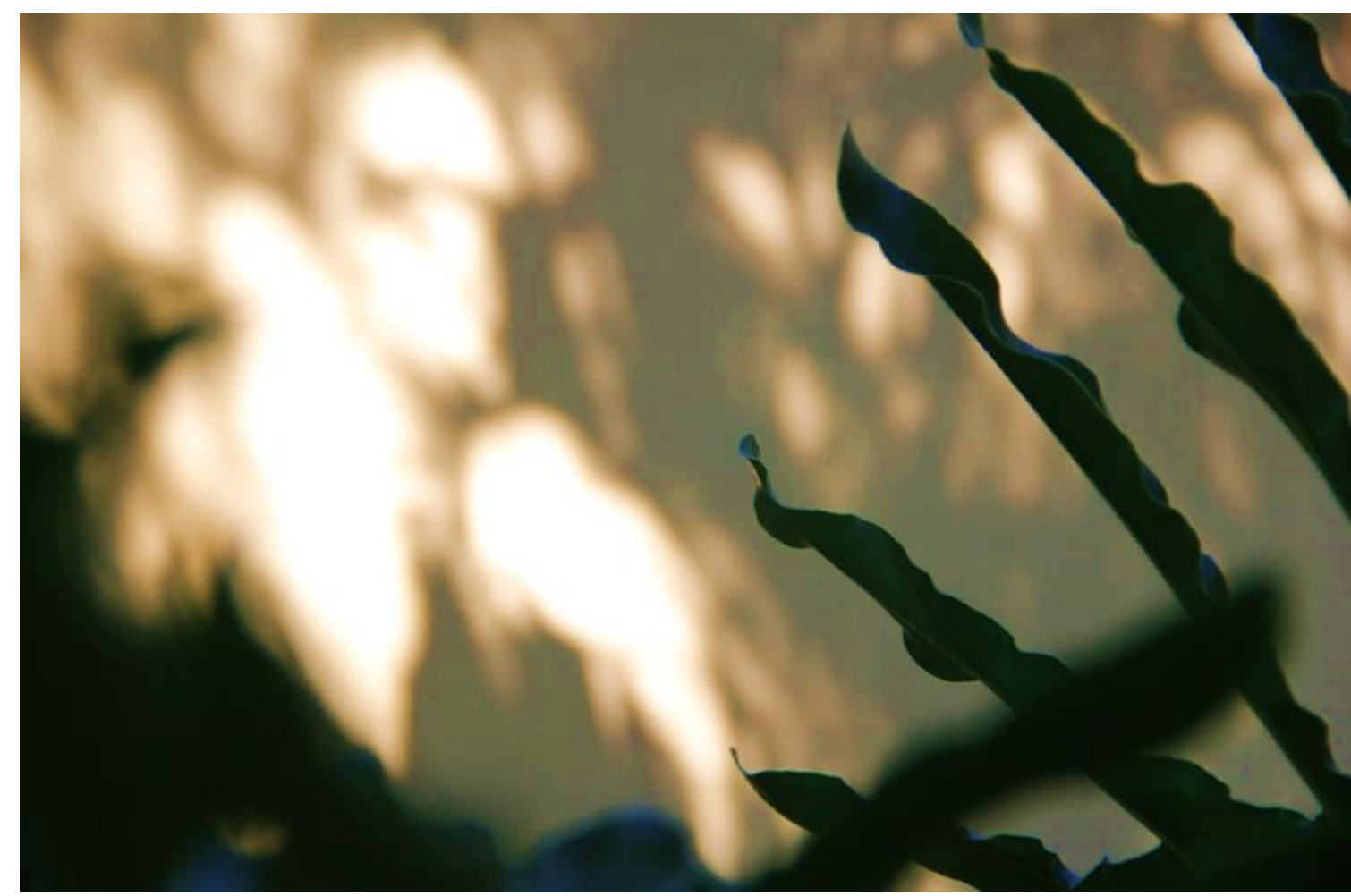

Imagem 7: foto de Pawanã Crodi Kariri-Xocó

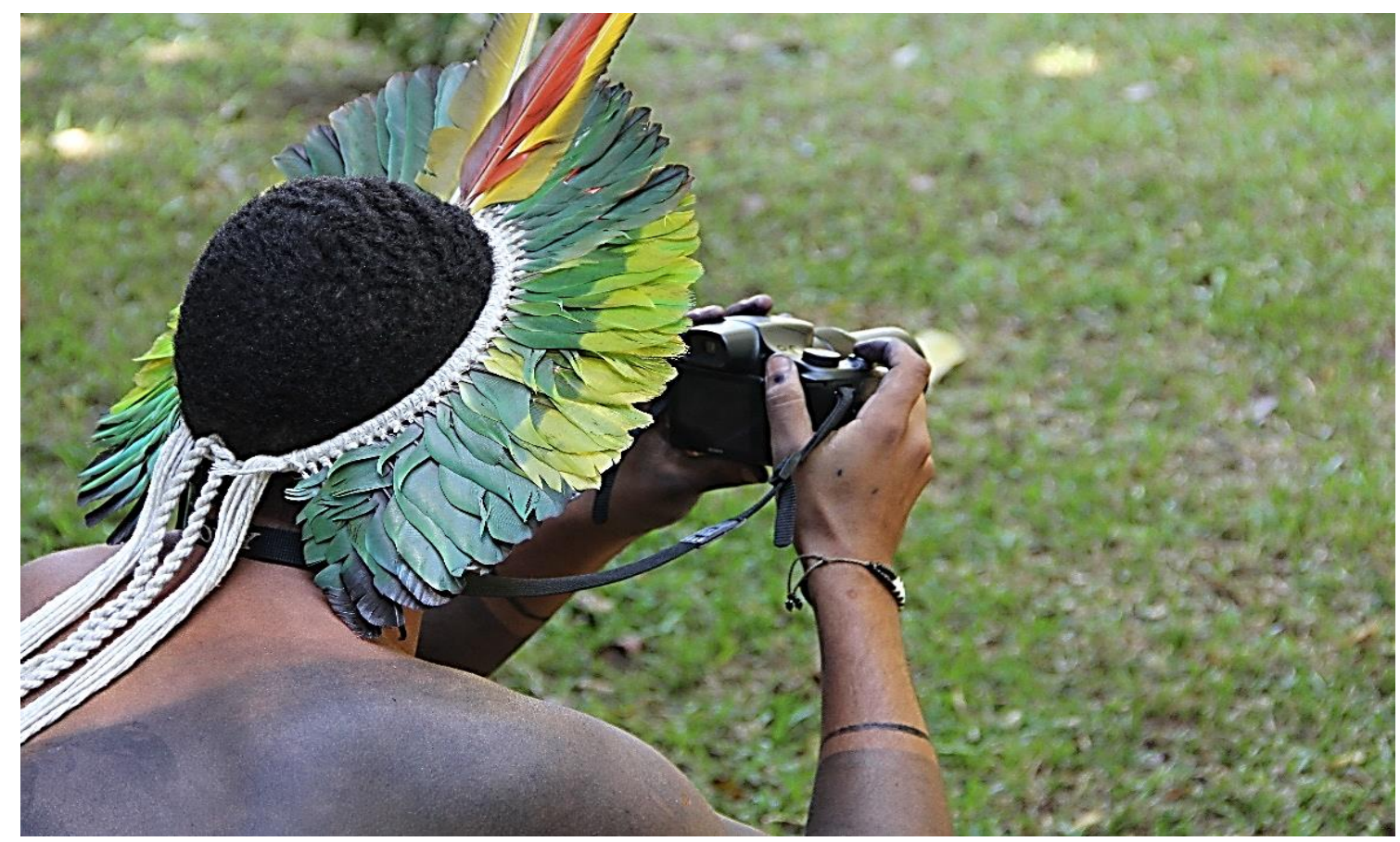

Imagem 8: foto de Miki Narita - Kaony fotografando

A inesperada entrada do devir-planta em no exercício fotográfico com os Kariri Xocó pode ser pensada como um ponto de partida para nossas experimentações que se

Rev. Eletrônica Mestr. Educ. Ambient. Rio Grande, Dossiê temático "Imagens: resistências e criações cotidianas", p. 28-42, jun. 2020. E-ISSN 1517-1256 
deram entorno da criação de imagens do "mundo das plantas" em nossos ateliês experimentais. A pergunta que nos mobilizou foi: o que levou os Kariri-Xocó ao impulso alegre de fotografar o ponto de vista das plantas? Fotografar o mundo pela perspectiva de uma planta é um exercício pouco provável em nosso regime de visualidade ocidental e beira o sem-sentido, quando entendemos que uma planta não tem órgãos de visão. Chamou-nos atenção a entrada imediata deles neste campo de possíveis. Como as relações que se estabelecem entre os Kariri-Xocó e o mundo das plantas possibilitam esta potente ação das plantas em seus processos de criação, em suas artes, e seus cantos, em suas práticas de cura? As memórias também encontraram sons e cores para árvores, as árvores contaram música. Fomos nos juntando às arvores, escutando as folhas e elas nos ouvindo atentas, o que contávamos delas.

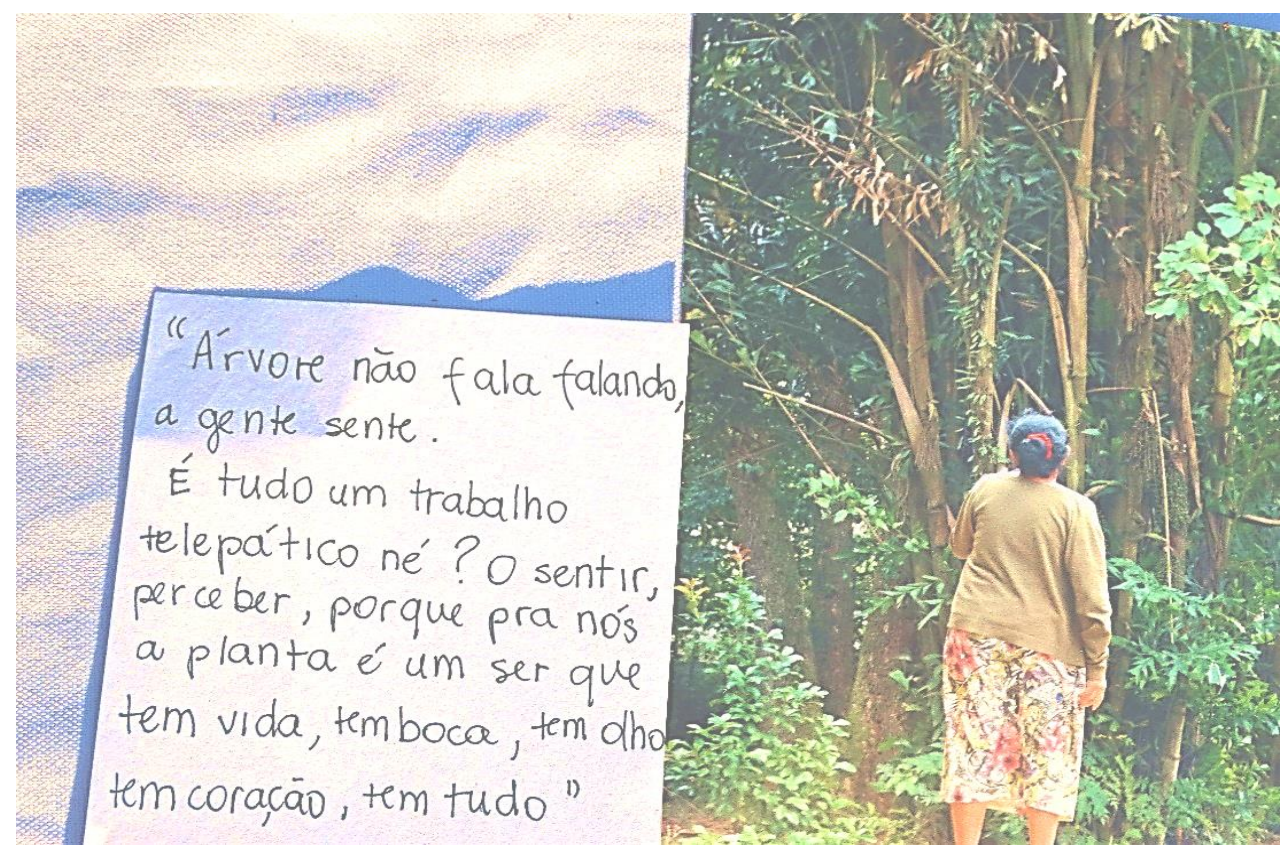

Imagem 9: foto e montagem de Alik Wunder a partir de narrativa de Pawanã Crodi e foto de Dé Kariri-Xocó

Dé Kariri-Xocó, mestra louceira, tem voz de terra: “Às vezes eu me acordo, até de madrugada, e vou lá. Me sento e conto para a árvore meu sonho. E quando conversamos, quando a comunicação está lá, elas cantam e nos dão música. 'Pau pendeu lá na mata, lá na mata o pau pendeu, lá na mata ninguém viu, o pau pendeu, só quem viu fui eu o pau pendido'. Essa é a música que o pau canta lá da mata pra gente.” (Dé Kariri Xocó) 
‘Kaony tem voz de folha: "Nós temos o conhecimento com a terra. Nossa experiência é com a terra, com as árvores. Nós sabemos que vamos plantar lá, temos a certeza que ela vai prosperar, sabemos que vai crescer, vai dar frutos, vai dar... Quando nós queremos entrar na mata para procurar um remédio, nós, pedimos autorização a ela para retirar aquela erva que temos necessidade. E ela então passa que nós podemos tirar. Tudo isso acontece na parte espiritual. Esse é o contato que temos com as árvores". (Kaony Kariri-Xocó)

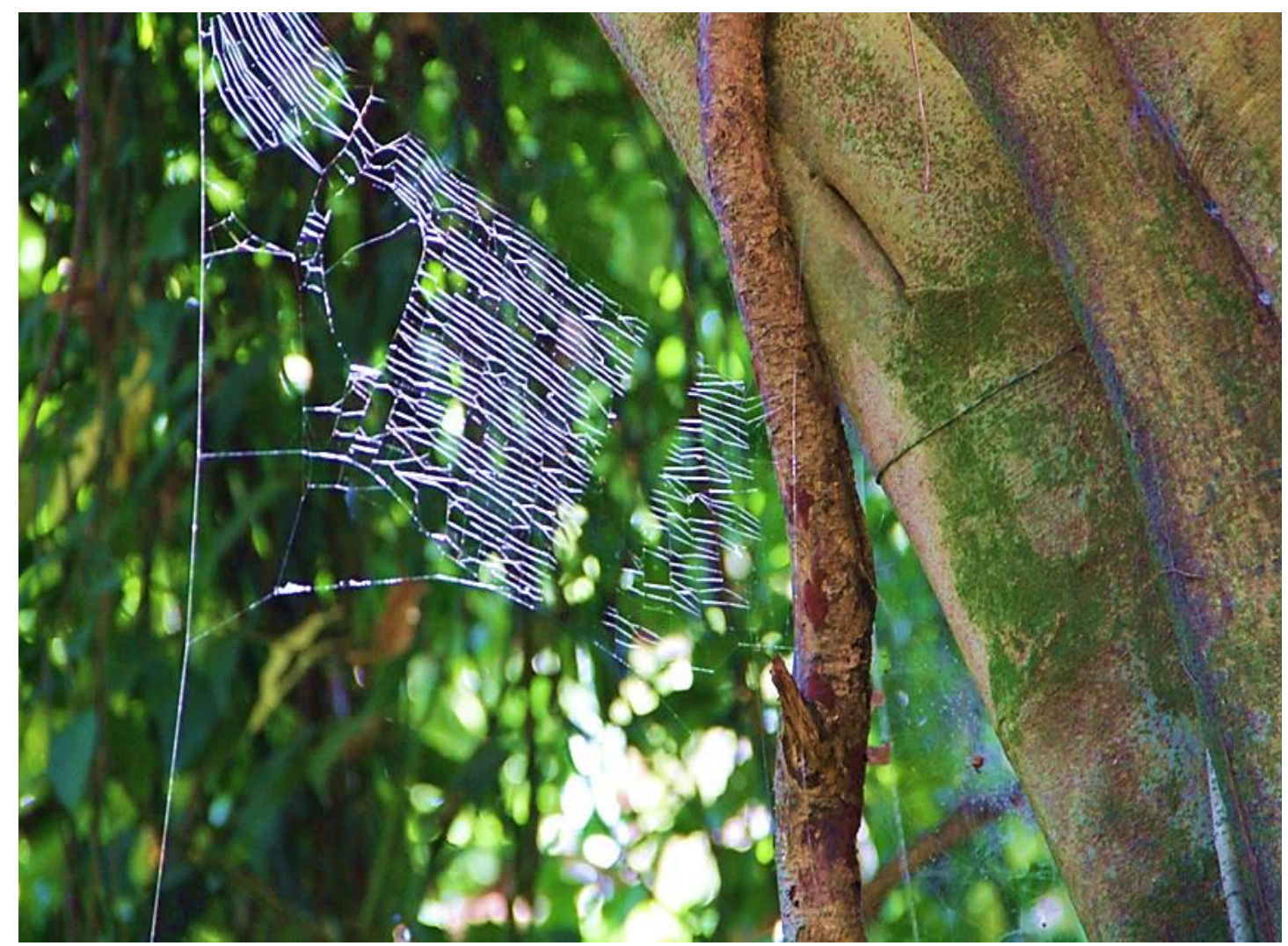

Imagem 10: foto de Kaony Kariri-Xocó

Pawana tem voz de raiz: "A gente entende a planta como nossa vida também. No mundo dela tem nossa mãe, nosso pai, nossos tios, tem aquela planta que acaricia a gente, tem aquela que aconselha, tem aquela que lapida também. Tem aquela que cuida, que cura. Com isso a gente passa a conhecer como é a vida dela, no mundo vegetal dela. Elas pedem e a gente sente. É o sentir, o perceber, porque a planta é um ser que tem vida, tem boca, tem olho, tem coração, tem tudo...” (Pawanã Crodi Kariri-Xocó)

"Nas coisas mais simples é onde estão as coisas mais poderosas. E é aí que está a nossa religião, no Ouricuri. O ouricuri é um tipo uma palmeira que dá um coco bem 
pequeno, ele dá na grota, na mata fechada e é este é o nome do nosso ritual, do nosso lugar sagrado. A palha a gente usa paras as saias, para os telhados que aguenta um ano de chuva e sol. O coco do ouricuri, você não quebra, ele é muito duro. Dentro do ouricuri só entra uma lagarta, tão frágil que se olhar demais ela até morre. E só ela assim bem mole é que consegue entrar no coco duro do Ouricuri, Cada um tem seu tempo, tem seus mistérios e a semente tem essa resistência. Por isso nosso ritual se chama Ouricuri, nossa resistência.” (Pawanã Crodi Kariri-Xocó)

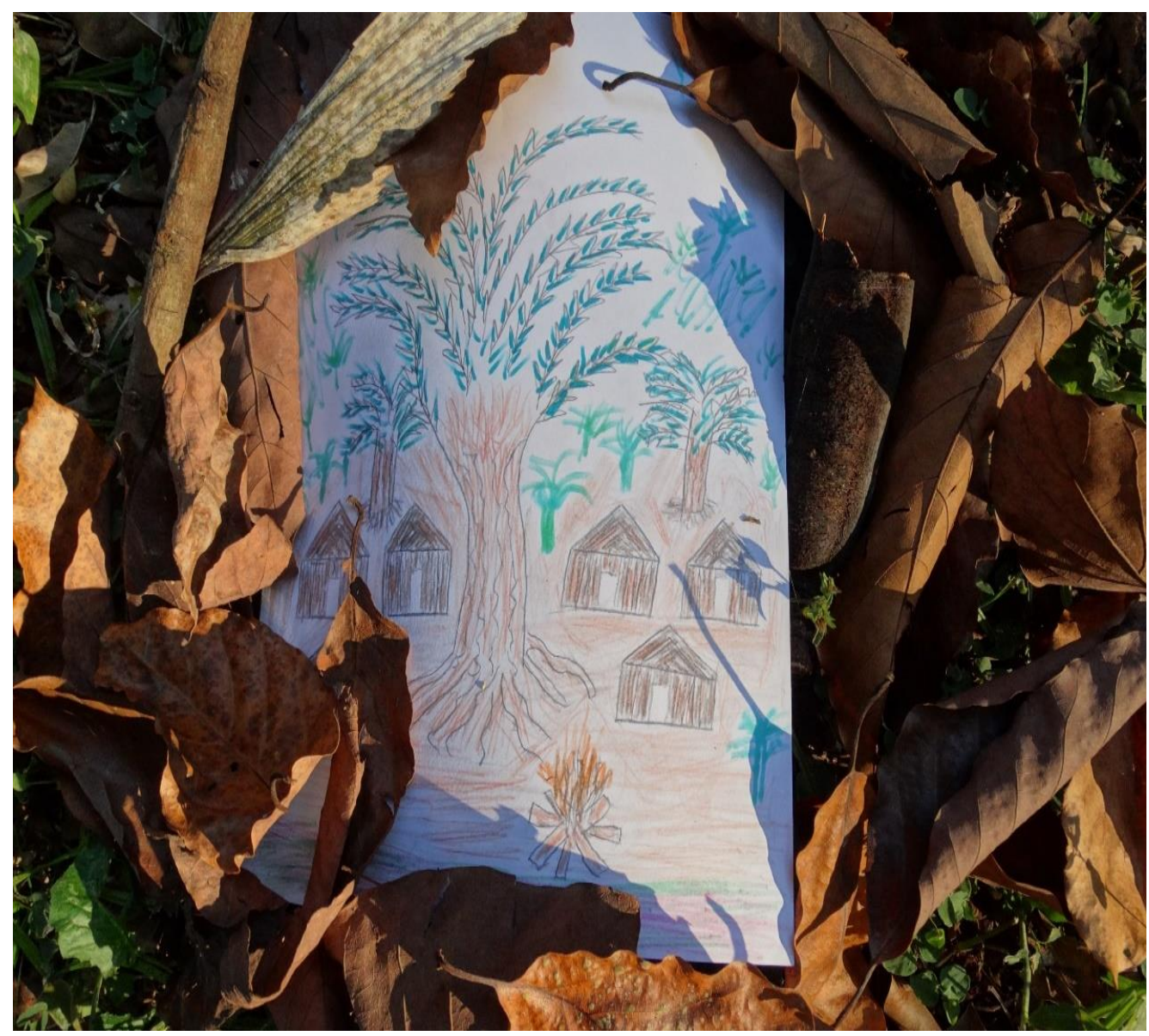

Imagem 11: Desenho de Iaru Kariri-Xocó e fotografia de Alik Wunder 


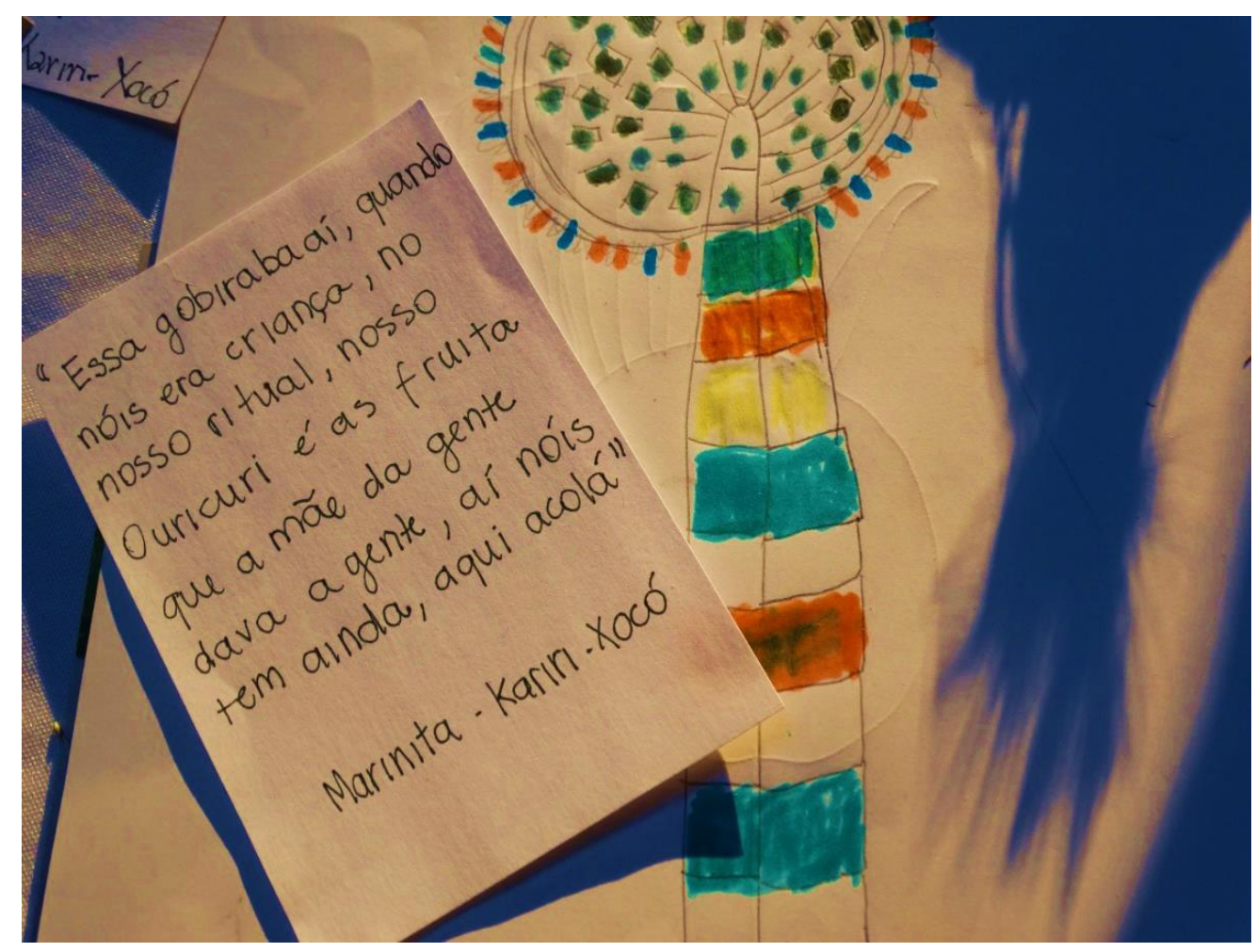

Imagem 12: foto de Alik Wunder - Desenho e narrativa de Marinita Kariri-Xocó

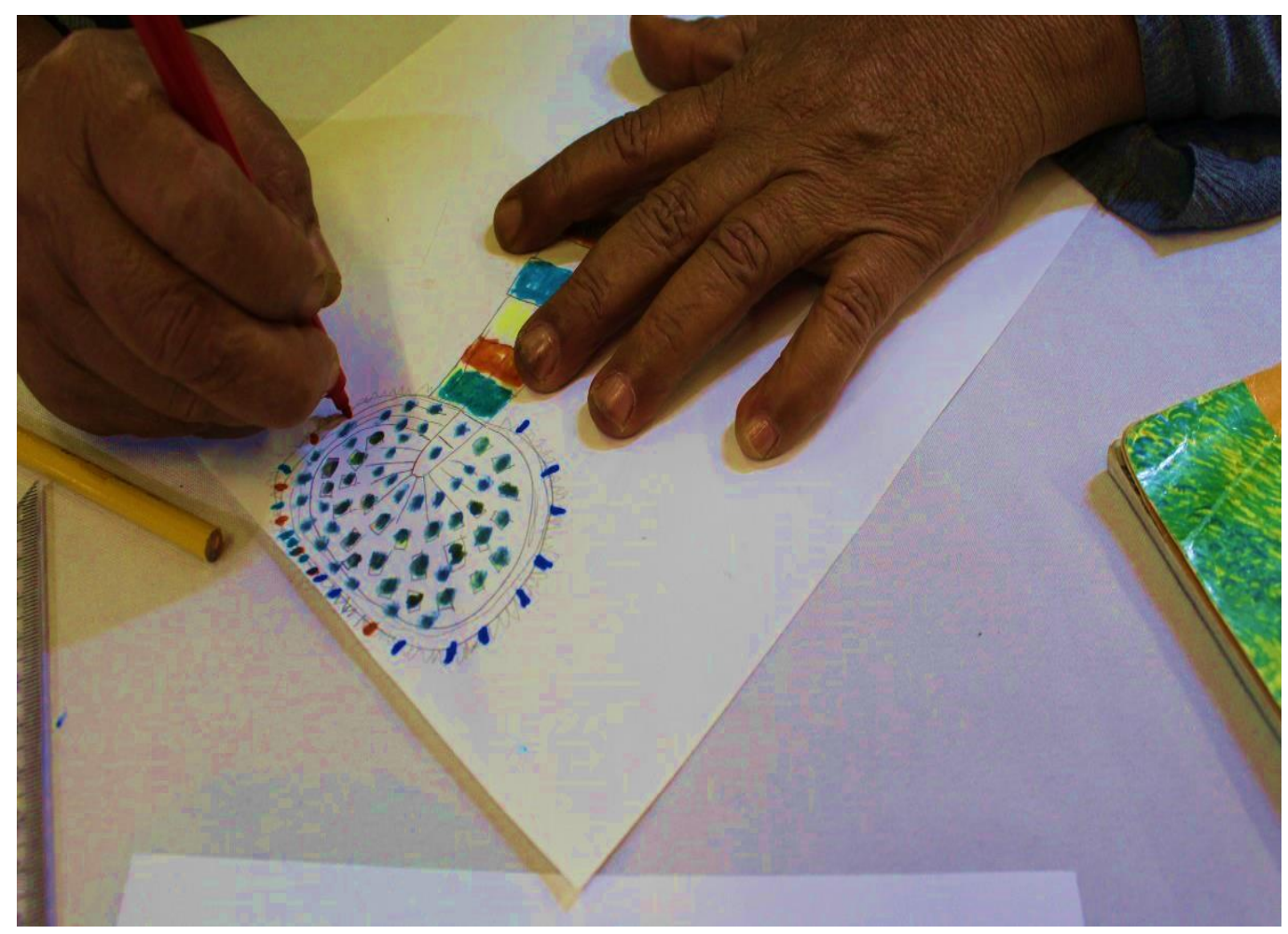

Imagem 13: foto de Alik Wunder - desenho de Marinita Kariri-Xocó

Rev. Eletrônica Mestr. Educ. Ambient. Rio Grande, Dossiê temático "Imagens: resistências e criações cotidianas", p. 28-42, jun. 2020. E-ISSN 1517-1256 


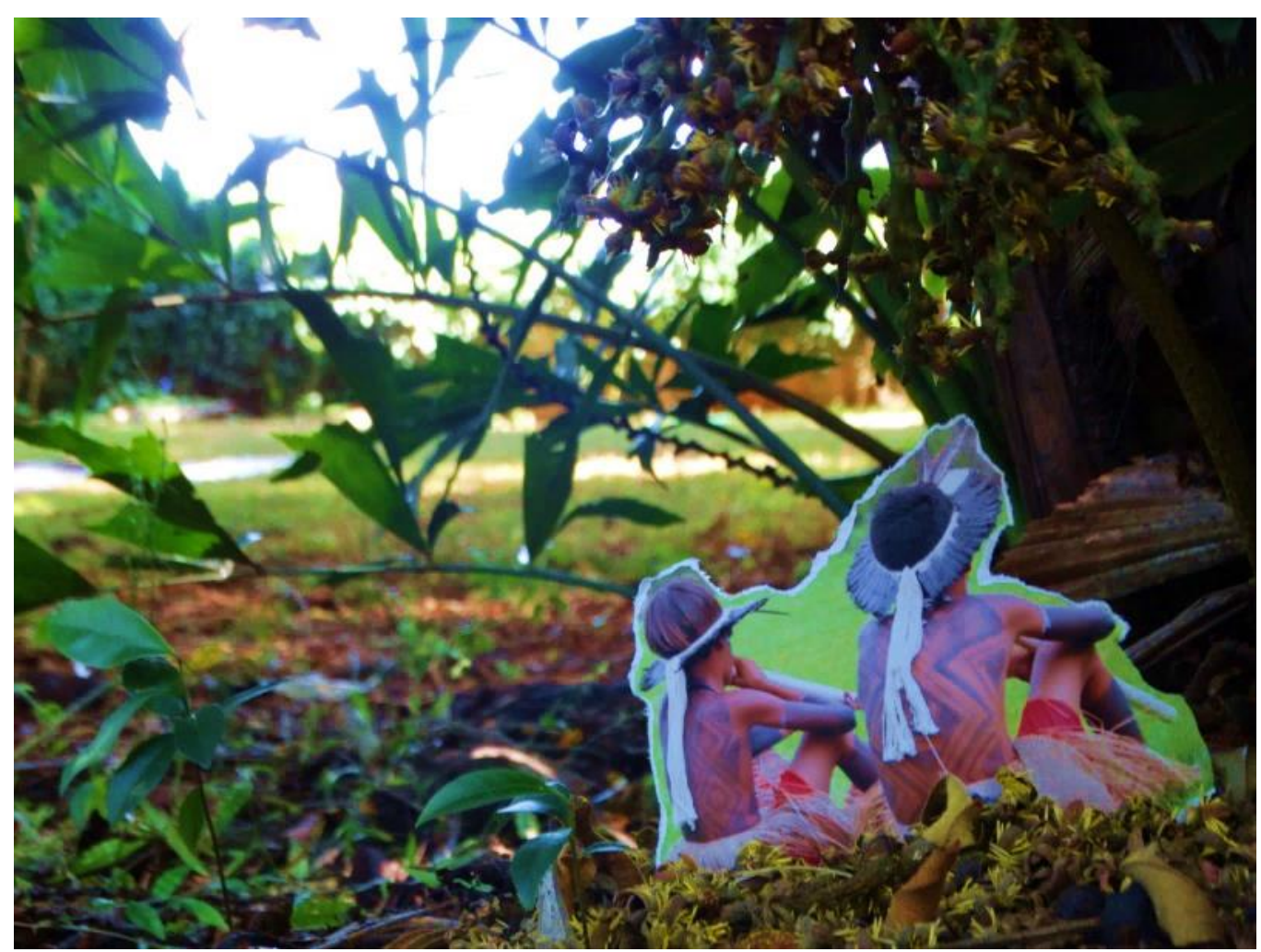

Imagem 14: foto de Alik Wunder

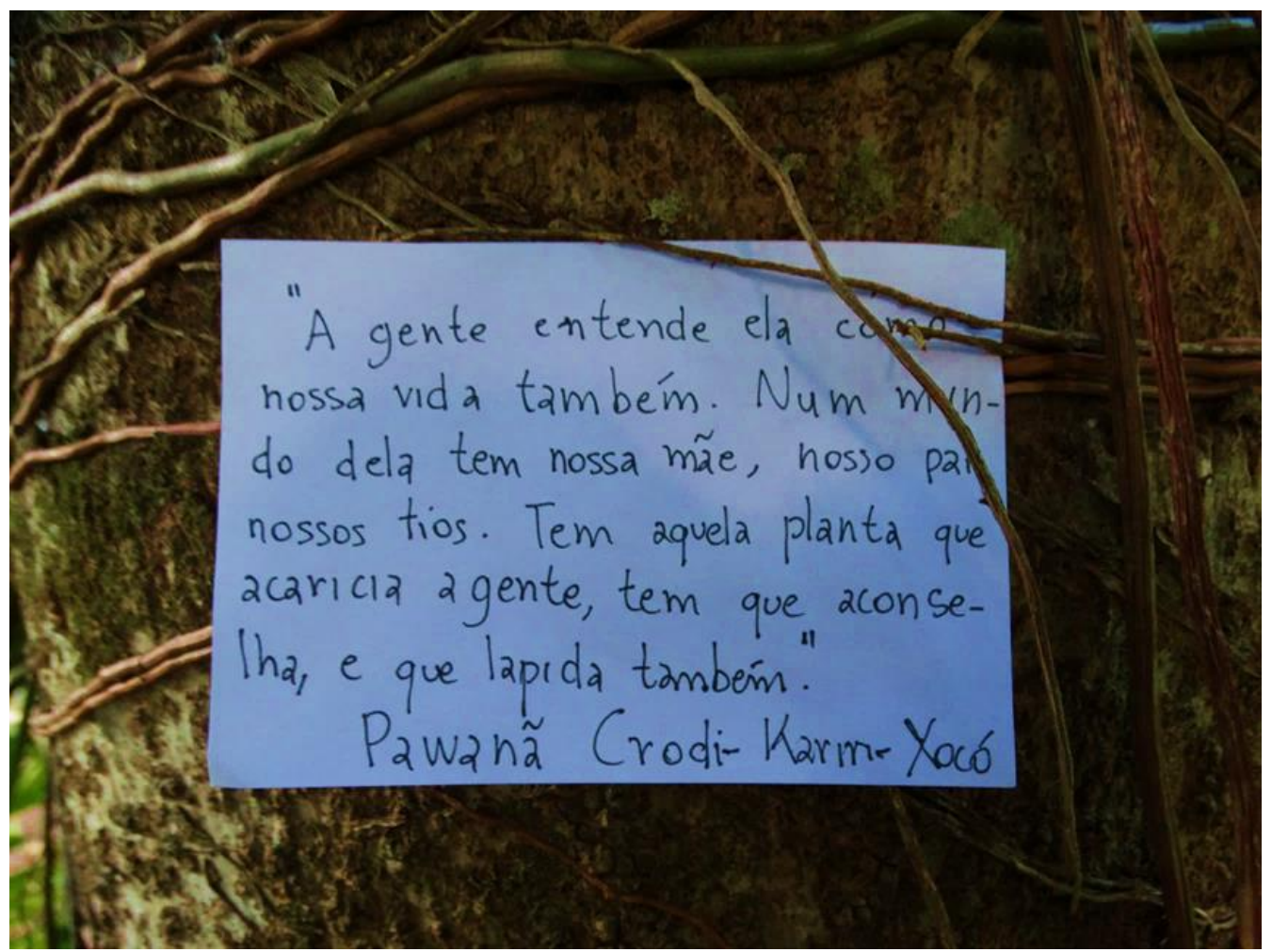

Imagem 15: narrativa de Pawanã Crodi e foto de Alik Wunder

Rev. Eletrônica Mestr. Educ. Ambient. Rio Grande, Dossiê temático "Imagens: resistências e criações cotidianas", p. 28-42, jun. 2020. E-ISSN 1517-1256 


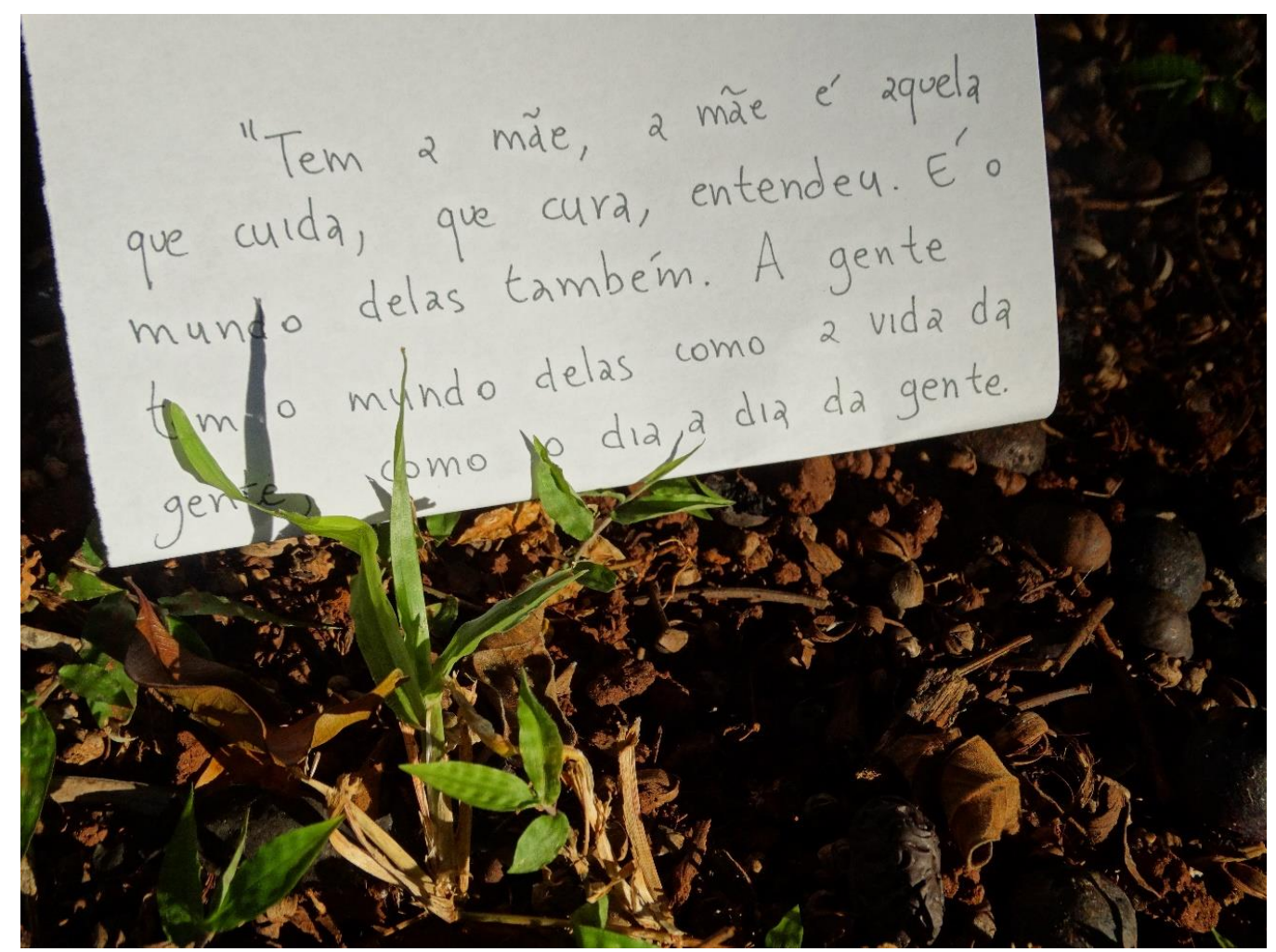

Imagem 16: foto de Alik Wunder a partir de narrativa de Pawanã Crodi

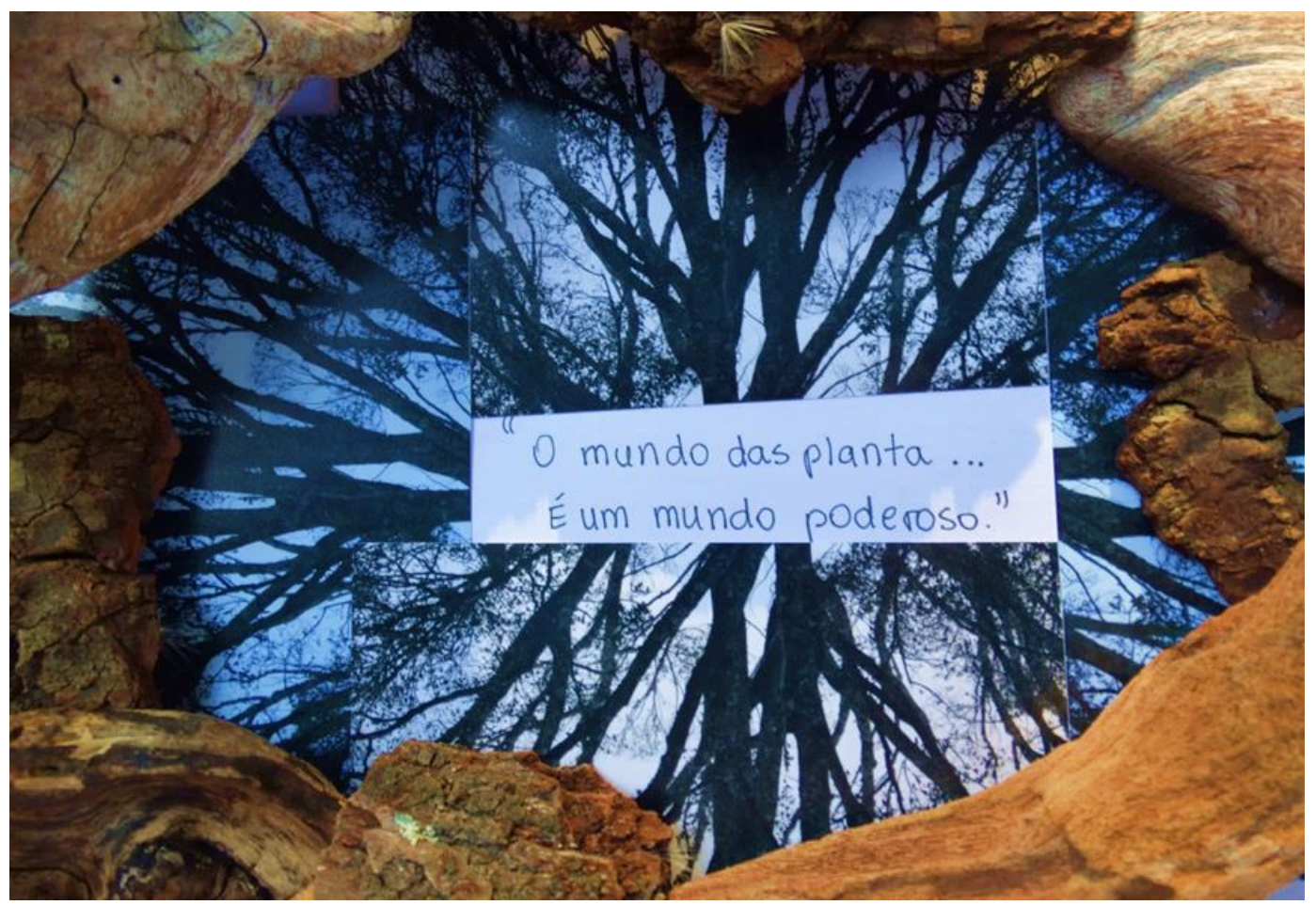

Imagem 17: foto de Alik Wunder - narrativa de Pawana Crodi

Rev. Eletrônica Mestr. Educ. Ambient. Rio Grande, Dossiê temático "Imagens: resistências e criações cotidianas", p. 28-42, jun. 2020. E-ISSN 1517-1256 
Para os Kariri Xocó as árvores escutam sonhos, dão conselhos, castigam e curam, deixam conhecer seu mundo vegetal em um modo de conversação aberta... Há uma fronteira que se abre em momentos especiais: momentos de necessidade, de doença, de crises, enquanto se fuma o pawi, no ritual... e no ponto mais forte desta conversação, os cantos são dados pelas árvores como um ensinamento que vão além do uso material para a realização de curas. Há uma comunicação que se faz nesta zona fronteiriça, desta subjetividade ambivalente gente-planta que se faz em sonho, em intuição, no momento que as linhas da pintura corporal aparecem nos corpos... Os corpos são a todo tempo riscados com a fruta do jenipapo e fazem do corpo um devirplanta, as marcas das pinturas não significam, instauram devires na pele: o devir cobra, devir-tartaruga, linhas que abrem zonas de vizinhança com outros reinos. Parece haver nas várias expressões da arte Kariri-Xocó, na sua arte material, nos cantos um devir vegetal que se dá nesta fronteira aberta entre o que chamamos de humano e inumano. Os indígenas nos trazem imagens de uma natureza que passa longe de ser apenas fonte de recursos. As ervas, as árvores e a floresta são povoadas de intencionalidades, sujeitos, seres, espíritos que cuidam há milhares de anos de tudo o que existe. Devires que proliferam alegria, germina e ramificam modos outros de estar no mundo, outras formas de pensar e criar.

Notas de fim:

1. Participantes do Ateliês de experimentação (2017 e 2018): Coletivo Fabulografias: Alik Wunder, Ana Carolina de Oliveira, Miki Narita, Marli Wunder. Grupo Sabuká Kariri-Xocó: Pawana Crodi Kariri-Xocó, Iaru Kariri-Xocó. Kauan Kariri-Xocó, Marinita Kariri-Xocó, Nary Kariri-Xocó, Valdete (Dé) Kariri-Xocó, Kaony Kariri-Xocó, Dirã Kariri-Xocó.

Submetido em: 11-05-2020. Publicado em: 01-07-2020. 